\title{
THE IMPLEMENTATION OF JIGSAW TECHNIQUE IN TEACHING READING COMPREHENSION
}

\author{
Jaenal Mutaqin ${ }^{1}$, Acep Haryudin ${ }^{2}$ \\ ${ }^{1}$ IKIP Siliwangi \\ ${ }^{2}$ IKIP Siliwangi \\ ${ }^{1}$ jaenal-mutaqin@ student.ikipsiliwangi.ac.id, ${ }^{2}$ haryacep@gmail.com
}

\begin{abstract}
Reading is considered an important aspect for students because of its valuable benefits in developing knowledge. In English, one of the skills that must be mastered is reading skill. However, to comprehend the contents of the text well there were still many students who find it difficult, it is caused by inappropriate technique used by teachers in teaching English. Therefore, to improve their reading comprehension proper technique must be applied. The aim of this reseach is to investigate whether there was an improvement by using jigsaw technique in students' reading comprehension in eighth grade students at SMPN 2 Pasirkuda. The researcher used 33 students as a sample of this research using a preexperimental design. The research instrument used a test in the pre-test and post-test. The result of this research presents that using jigsaw technique had the positive effect in improving reading comprehension. We can see the results from paired samples t-test that there is a significant difference for the pre- test score $(M=47.45, S D=7,55)$ and post-test $(M=68.85, S D=6,38), t(32)=-19,40, p$ $<0.05$. It concluded that the jigsaw technique improve the students' reading comprehension.
\end{abstract}

Keywords: Jigsaw Technique, Reading Comprehension

\section{INTRODUCTION}

Learning English and other foreign languages purposes as a means of communication to access information and share it globally to build interpersonal relationships and to increase insight into foreign cultures. In Indonesia, we know that English is generally studied by students as a foreign language. Foreign languages are taught as one of the mandatory subjects in class with the basic purpose of communicating. In learning English, there are four reading skills that must be mastered by students one of which is reading skills. Reading is really a very important skill for students to learn. Through reading, students can get a lot of information from the text.

According to Dreyer (1998:18) as cited in (Haryudin, 2019) reading is the most important skill that must be possessed by second language learners in an academic context. It is supported by Campbell (1995 cited in Apsari, 2016), reading is the most is useful skill for foreign language learners since a reading skill mastery is the key for a successfull academic life, a widen horizon, and an access to new knowledge and information. It means that reading is the process of getting the message presented by the author in the text and it is one way for us to get all the information contained therein. As claimed by He Ji Sheng (2000) in (Halimah \& Helpiana, 2019) reading is the process of acknowledging, interpreting, and perceiving written or printed material. This involves the introduction of words, clauses, phrases and letters. This process can be considered a simpler process than just comprehension. In addition, understanding is a process of deep understanding between the reader and the writer. 
Reading comprehension becomes very important for everyone to enrich their knowledge. This idea is supported by Walter (2004) as cited in (Sumiati, Rizka, \& Zulkaidah, 2019) reading comprehension is the interaction of information carried out between readers who take information from a text and the reader's expectations or information about the text that has been read. Reading is an activity informed by the apprehension of images, shapes, patterns, and rhythms, which come to be recognized through repeated encounters and remembered forms; the meanings that are made in reading are in excess of the meanings that arise from the interpretation of written language (Lorange, 2014: 30) as cited in Parmawati (2018). Reading comprehension is an activity or process of how students can understand and get information or content from text.

The target of reading activity is students should have the ability to read comprehension to build a good understanding of English texts. But in reality, students are very difficult and cannot understand English well. The contributing factors are that learning techniques are not appropriate and still the conventional method used by teachers in teaching English, so students do not seem to have good motivation to read and they have many difficulties to interpret the meaning of texts, it causes they do not know what is the meaning and the main idea of the text. Based on the problem, researcher is interested in trying to apply jigsaw techniques as a solution of the problem in Junior High School to improve students' reading comprehension.

\section{Definition of Reading Comprehension}

Reading comprehension is the main pillar in reading activities where a reader builds understanding of a text. He combines logical thinking that is owned with a collection of letters, words, and sentences in the text. According to Duke \& Pearson (2001: 423) as cited in (Facharyani, Masrupi, \& Rahmawati, 2018) that reading comprehension is the process by which the reader constructs meaning as building material for information about knowledge stored in the reader's head. As stated in Snow (2002) cited in Wood, Moxley, Tighe, \& Wagner (2018) Reading comprehension, which is defined as the ability to construct meaning from interacting with a text, it is very important for students in achieving success in today's every level of education. So, reading comprehension in English text is not just about how you read well, which includes the accuracy of pronunciation and loud sounds. Walter (2004) in Sumiati et al., (2019) defined reading comprehension as the interaction of information between readers who take information from a text and the expectations of readers or information about text that has been read.

\section{Definition of Jigsaw}

Jigsaw is one of the technique in cooperative learning that can be used. As stated in Haryudin, A., \& Argawati (2018) that jigsaw is a technique belonging to cooperative approaches which enable students to work in group discussion. Jigsaw technique is a method of learning to organizing student activities in class that makes students responsible and depend on each other to succeed. Cooperative learning is a group learning activity that is organized so that the learning process depends on the socially structured exchange of information between students in the group and where each student is responsible for his own learning and motivated to help and enhance the learning of others. (Carolyn Kessler, 1992:8) as cited in (Ahmada, 2019). According to Brown (1994:182) as cited in Silalahi (2019) that jigsaw method that as special form of information gap in which each member of a group is given some specific information to achieve some objective. In jigsaw technique students work with one another in small groups where they have to rely on each other. It supported by Yuhananik (2018) that each group member becomes "specialized" in subject matter and thereby possesses critical information to 
contribute to classmates. Here, cooperation and mutual trust become valuable and necessary to academic achievement. The main objective of jigsaw is to make each team member become responsible for certain learning, and then share the work with his or her teammates (Stone, 1990:41) as cited in Yuhananik (2018).

\section{METHOD}

In this research, the researcher used Pre-experimental design. The data was taken from 33 Students of VIII A class in SMP Negeri 2 Pasirkuda-Cianjur. To collect data the researcher used two tests, there are pre-test and post-test. According to Arikunto (2006:85) as cited in (Nurbianta \& Dahlia, 2018) states that in this design observations will be made twice, namely before the treatment called pre-test and after treatment called post-test. Then, the score of the research results were calculated through SPSS to find out whether the jigsaw technique was effective in improving students' reading comprehension.

\section{RESULTS AND DISCUSSION}

\section{Results}

Here is the report of concerning the results of data by the pre-test and post-test. The following is a table of test score results:

Table 1. Score of Students

\begin{tabular}{|c|c|c|c|c|}
\hline No & Name & Gender & Pre-test & Post-test \\
\hline 1 & Student 1 & $\mathrm{M}$ & 42 & 62 \\
\hline 2 & Student 2 & $\mathrm{M}$ & 46 & 64 \\
\hline 3 & Student 3 & $\mathrm{~F}$ & 58 & 82 \\
\hline 4 & Student 4 & $\mathrm{M}$ & 42 & 66 \\
\hline 5 & Student 5 & $\mathrm{M}$ & 54 & 70 \\
\hline 6 & Student 6 & $\mathrm{M}$ & 38 & 60 \\
\hline 7 & Student 7 & $F$ & 52 & 70 \\
\hline 8 & Student 8 & $\mathrm{~F}$ & 48 & 66 \\
\hline 9 & Student 9 & $\mathrm{~F}$ & 40 & 74 \\
\hline 10 & Student 10 & $\mathrm{~F}$ & 62 & 80 \\
\hline 11 & Student 11 & $\mathrm{~F}$ & 42 & 62 \\
\hline 12 & Student 12 & $\mathrm{M}$ & 40 & 68 \\
\hline 13 & Student 13 & $\mathrm{M}$ & 58 & 72 \\
\hline 14 & Student 14 & $\mathrm{M}$ & 50 & 68 \\
\hline 15 & Student 15 & $\mathrm{M}$ & 38 & 60 \\
\hline 16 & Student 16 & $\mathrm{~F}$ & 38 & 70 \\
\hline 17 & Student 17 & $\mathrm{M}$ & 52 & 66 \\
\hline 18 & Student 18 & $\mathrm{~F}$ & 46 & 76 \\
\hline 19 & Student 19 & $\mathrm{M}$ & 48 & 74 \\
\hline 20 & Student 20 & $\mathrm{M}$ & 38 & 74 \\
\hline 21 & Student 21 & $\mathrm{M}$ & 58 & 64 \\
\hline 22 & Student 22 & $\mathrm{~F}$ & 56 & 78 \\
\hline
\end{tabular}




\begin{tabular}{lllll}
\hline 23 & Student 23 & F & 50 & 70 \\
\hline 24 & Student 24 & M & 44 & 66 \\
\hline 25 & Student 25 & M & 48 & 62 \\
\hline 26 & Student 26 & M & 40 & 58 \\
\hline 27 & Student 27 & F & 62 & 76 \\
\hline 28 & Student 28 & P & 56 & 80 \\
\hline 29 & Student 29 & P & 50 & 66 \\
\hline 30 & Student 30 & P & 46 & 72 \\
\hline 31 & Student 31 & M & 40 & 66 \\
\hline 32 & Student 32 & M & 36 & 60 \\
\hline 33 & Student 33 & P & 48 & 70 \\
\hline
\end{tabular}

In the description of the data, the researcher calculated the data using SPSS 18 with the following outputs:

\begin{tabular}{|c|c|c|c|}
\hline \multicolumn{4}{|c|}{ Table 2. Descriptive Statistics } \\
\hline & $\mathrm{N}$ & Mean & Std. Deviation \\
\hline Pretest & 33 & 47,45 & 7,55 \\
\hline Posttest & 33 & 68,85 & 6,38 \\
\hline Valid N (listwise) & 33 & & \\
\hline
\end{tabular}

Table 2 shows that the mean scores of post-test $(63,58)$ is bigger than the mean score of pretest $(47,45)$. This means that there is a significant increase in students' reading comprehension. Then, score of Std. Deviation of pre-test $(7,55)$ is bigger than Std. Deviation of post-test $(6,38)$. The results can be concluded that the post-test score are more homogeneous with the pre-test score.

\begin{tabular}{lrrrrrr}
\hline \multicolumn{7}{c}{ Table 3. Tests of Normality } \\
\\
\hline
\end{tabular}

Based on table 3, it shows that the value of $p$ (Sig.) are $0.18 \& 0.09$ respective, because the $p$ (Sig.) values are bigger than 0.05 , the pre-test scores are normally distributed. Besides that, the value of $\mathrm{p}$ (Sig.) are $0.19 \& 0.38$ respective, because the $\mathrm{p}$ (Sig.) values are bigger than 0.05 , the post-test scores are distributed of normally. For that reason, the paired t-test is used to detect the mean score between pre-test and post-test. 


\begin{tabular}{|c|c|c|c|c|c|c|c|c|c|}
\hline \multicolumn{10}{|c|}{ Table 4. Paired Samples Test } \\
\hline & & \multicolumn{5}{|c|}{ Paired Differences } & \multirow[t]{3}{*}{$\mathrm{t}$} & \multirow[t]{3}{*}{ df } & \multirow{3}{*}{$\begin{array}{l}\text { Sig. (2- } \\
\text { tailed) }\end{array}$} \\
\hline & & \multirow[t]{2}{*}{ Mean } & \multirow[t]{2}{*}{ Std. Deviation } & \multirow[t]{2}{*}{$\begin{array}{l}\text { Std. Error } \\
\text { Mean }\end{array}$} & \multicolumn{2}{|c|}{$\begin{array}{c}\text { 95\% Confidence } \\
\text { Interval of the } \\
\text { Difference }\end{array}$} & & & \\
\hline & & & & & Lower & Upper & & & \\
\hline $\begin{array}{l}\text { Pair } \\
1\end{array}$ & $\begin{array}{l}\text { Pretest - } \\
\text { Posttest }\end{array}$ & $-21,39$ & 6,33 & 1,10 & $-23,64$ & $-19,14$ & $-19,40$ & 32 & ,00 \\
\hline
\end{tabular}

Table 4 is used to test the null hypothesis which states, "there is no significant improvement in students' reading comprehension after being taught through jigsaw technique". From the table 4, the p value (Sig.) Is 0.00 and smaller than 0.05. This means that the result of the null hypothesis is rejected. In other words, these results indicate there is a significant increase in students' reading comprehension after applying jigsaw technique in the teaching-learning process. Because it is significantly higher than 0.05 , it can be concluded that the test has a normal distribution. In addition, statistically significant effect sizes need to be calculated. By applying the following formula:

$$
\begin{aligned}
& \mathrm{d}=\frac{\mathrm{tdep}}{\sqrt{n}} \\
& \mathrm{~d}=\text { the effect of size } \\
& \mathrm{t}=\text { observed } \mathrm{t} \text { value } \\
& \mathrm{n}=\text { number of sample }
\end{aligned}
$$

The effect size of the treatment $(\mathrm{d})=3,37$, is categorized as large because it is more than 0.8 (Abott, 2011 in Sadikin, Suprijadi \& Kaswan, 2019) as cited in (Sumiati et al., 2019).

\section{Discussion}

This research was conducted in one class with implementation of pre-test, treatment and posttest in four meetings. At the first meeting, a pre-test was given to them. Then, researchers gave treatments twice using jigsaw techniques in the class. At the last meeting, a post-test was conducted on them to see improvements in students' reading comprehension.

Based on the calculation results, it can be concluded that in students' reading comprehension using jigsaw technique there is a very significant improvement. Through paired samples t-test to compare pre-test and post-test scores from jigsaw techniques. There were significant differences for pre-test scores $(M=47.45, S D=7,55)$ and post-test $(M=68.85, S D=6,38), t$ $(32)=-19,40, p<0.05$. In addition, the difference in mean scores was very large $(d=3,37)$. So, the jigsaw technique explains that 337 percent of the variation in reading comprehension.

Jigsaw techniques are very effective for improving students' reading comprehension. During treatment, in the process of teaching and learning activity researcher found that most students were actively involved. They are motivated to enthusiastically discuss and share information by applying jigsaw technique. It can be concluded that the treatment using jigsaw techniques has a large effect in teaching students' reading comprehension.

\section{CONCLUSION}

Based on the results and discussion, there is a significant improvement in students' reading comprehension using jigsaw. This is indicated by the fact that the post-test average score is bigger than the pre-test average score. In addition, the p value (Sig.) Is smaller than 0.05. 


\section{ACKNOWLEDGMENTS}

Bismillahirrahmanirrahiim. Alhamdulillahi rabbil alamin, praise and thanks are to Allah SWT, the God of all creatures. Because of His mercy and blessing, the author has been able to complete the writing of the article titled "The Implementation of Jigsaw Technique in Teaching Reading Comprehension" submitted as a final requirement in completing a bachelor's degree at English Language Education Study Program Language and Arts Department, IKIP Siliwangi Bandung.

This journal have not been completed without support, guidance from individual and institution. Therefore, the researcher would like to present sincere appreciation and express special thanks to:

1. Acep Harydin, M.Pd. as the advisor for their guidance and help to finish this journal.

2. Asep Sonny, S.Pd. MM. as the headmaster, and Dendi Efendi, S.Pd as the English teacher in SMP Negeri 2 Pasirkuda to contribute researcher who are conducting research in school.

3. All the students of the second semester of eighth grade in SMP Negeri 2 Pasirkuda for giving nice participation and great attention during the research.

4. Other researchers for reference in teaching use jigsaw technique to improve students' reading comprehension.

\section{REFERENCES}

Ahmada, A. (2019). The Effectiveness Of Jigsaw Learning Model In Teaching Reading Comprehension On Narrative Text. Jurnal Darussalam: Jurnal Pendidikan, Komunikasi Dan Pemikiran Hukum Islam, 10(2), 258.

Apsari, Y. (2016). Cloze Passage In Improving Students' Reading Comprehension. Eltin Journal, Journal Of English Language Teaching In Indonesia, 4(2), 53-62.

Facharyani, N., Masrupi, M., \& Rahmawati, E. (2018). The Influence Of Using Jigsaw As A Method On Students' Reading Comprehension At The Seventh Grade Of Smpn 7 Kota Serang. Journal Of English Language Studies, 3(1), 80.

Halimah, Helpiana Purba, C. R. (2019). Improving Students' Reading Comprehension Through Jigsaw Technique. Project (Professional Journal Of English Education), 2(2), 355-368.

Haryudin, A., \& Argawati, N. O. (2018). Lesson Study To Improve Student English Grammar Mastery Using Jigsaw Technique To The. Indonesian Efl Journal, 4(January), 56.

Haryudin, A. (2019). Improving Reading Skill Using Jigsaw. Project (Professional Journal Of English Education), 2(2), 126-132.

Nurbianta, N., \& Dahlia, H. (2018). The Effectiveness Of Jigsaw Method In Improving Students Reading Comprehension. Eternal (English Teaching Journal), 9(1), 70-86.

Parmawati, A. (2018). The Study Correlation Between Reading Habit And Pronunciation Ability At The Second Grade Students Of Ikip Siliwangi. Eltin Journal, Journal Of English Language Teaching In Indonesia, 6(1), 46-52.

Silalahi, E. B. (2019). Jigsaw Method In Reading Comprehension Jigsaw Method In Reading Comprehension. Enjourme (English Journal Of Merdeka): Culture, Language, And Teaching Of English, 4(January), 9-16.

Sumiati, C., Rizka, D., \& Zulkaidah, M. (2019). Teaching Reading Comprehension Using Jigsaw. Project (Professional Journal Of English Education), 2(4), 461-465.

Wood, S. G., Moxley, J. H., Tighe, E. L., \& Wagner, R. K. (2018). Does Use Of Text-ToSpeech And Related Read-Aloud Tools Improve Reading Comprehension For Students With Reading Disabilities? A Meta-Analysis. Journal Of Learning Disabilities, 51(1), 73 84. 
Yuhananik, Y. (2018). Using Jigsaw Model To Improve Reading Comprehension Of The Ninth Graders Of Smpn 1 Karangploso. Ijoltl: Indonesian Journal Of Language Teaching And Linguistics, 3(1), 51-64. 